\title{
DEVELOPMENT AND STANDARDIZATION OF A TOOL TO MEASURE KNOWLEDGE OF LABOUR LAWS AMONG EMPLOYEES
}

\author{
M. M. Sulphey ${ }^{1}$, Awad Ali Alanzi' ${ }^{2}$,Martin Klepek ${ }^{3}$
}

\footnotetext{
1 Prince Sattam Bin Abdulaziz University, College of Business Administration, Department of HRM, Saudi Arabia, ORCID: 0000-0001-6042-2123, s.manakkattil@psau.edu.sa;

2 Prince Sattam Bin Abdulaziz University, College of Business Administration, Department of Law, Saudi Arabia, ORCID: 0000-0003-4219-7334, a.alwitheri@psau.edu.sa;

3 Silesian University in Opava, School of Business Administration in Karviná, Department of Business Economics and Management, Czech Republic, ORCID: 0000-0003-4058-156X, klepek@opf.slu.cz.
}

\begin{abstract}
Labour legislations provide guidelines to prevent unfair labour practices and organizational injustice. All employment and labour laws propose standards regarding wages, wellbeing, safety, and equitable treatment, which reduces conflicts. However, informational imbalances between employers and employees prevent employees from having adequate knowledge about labour legislation. Consequently, some employers treat employees inconsistently and that could be detrimental to them. A practical solution to this problem is making employees aware of the provisions of labour laws. As an initial step towards this, there is a definite need to assess employees' awareness regarding labour laws. Nevertheless, there is a lack of a standardized tool to measure the knowledge level of labour legislation, which has impaired empirical examinations. Using randomly collected 346 samples from two different types of industries, the present study constructed and validated a tool to measure labour law knowledge. The study has followed a simple scale development framework consisting of item generation, scale development, and psychometric evaluation. The measurement tool has been developed using exploratory and confirmatory factor analysis. The final questionnaire consists of 17 items under four factors, exhibited significant reliability and validity. The developed tool is expected to fill the gap in the literature and stimulate further empirical research. The study also examined the difference in the knowledge level based on the demographics of the sample. The results show a significant difference between the knowledge levels based on gender, citizenship, type of industry, and qualifications. Future research directions are proposed at the end of the paper, together with the limitations of this study.
\end{abstract}

Keywords: Labour laws, employer-employee relations, Saudi Arabia, scale development, organizational justice.

JEL Classification: J53, K31.

APA Style Citation: Sulphey, M. M., Alanzi, A. A., \& Klepek, M. (2021). Development and Standardization of a Tool to Measure Knowledge of Labour Laws among Employees. E\&M Economics and Management, 24(4), 86-104. https://doi.org/10.15240/tul/001/2021-4-006

\section{Introduction}

In the current world, there is an informational imbalance in employer-employee relationships (Cabrelli, 2019). While employers usually enjoy higher levels of resources, expertise, and access to information about labour conditions, employees are disadvantaged than employers as they have to face multiple issues and barriers. Employees are in a difficult situation concerning contract negotiation and writing. Due to better resources, employers are in a better place regarding eliciting unilaterally favourable contractual terms. As employers have a form of monopoly, they tend to be involved in 
intimidating and unprincipled behaviours like treating employees inconsistently, which could be detrimental (Deakin, 2012). There is also a gap in the process of monitoring and enforcement of contractual obligations (Wachter, 2012). This situation tends to affect employees far more than an employer, e.g. any cost overrun for the employer is often passed down indirectly to employees in reduced compensation and deferred benefits. Organizational justice can help in reducing such imbalances and influencing employee attitudes and relationships. Adverse perceptions in employees' minds due to labour issues can lead to poor performances, conflicts, reduced trust, and commitment (Yean \& Yusof, 2016). Interestingly, despite the important nature of the issue, organisational injustice is rarely the subject of employer attractiveness perceived by potential employees (Bellou et al., 2015; Eger et al., 2019).

Employer-employee relationships are subjected to labour legislation and regulations, which ensure harmonious relationships between them. Labor legislation provides guidelines for preventing unfair labour practices and organizational justice (Sotshononda, 2019). All employment and labour laws propose standards regarding wages, well-being, safety, and equitable treatment, which reduces conflicts. Across the globe, frameworks to protect workers came into being more than a century back. As a result, governments focused on labour relations and enacted many new labour laws regarding wages, working hours, and dealing with retributions, putting stricter working conditions in place. Now there are multiple dimensions to labour relations that have many different dimensions and contradictions.

Focusing on these dimensions and contradictions within them, Davidov (2007) asserted: "In labour relations, there is trust alongside mistrust; merger of interests alongside conflict of interests; rational behaviour alongside irrational behaviour; inefficiencies alongside efficiencies. Labour law should be sensitive to all of these dimensions and, to a large extent, it is. The extensive body of labour law includes regulations that can be seen as correcting market failures, alongside regulations that accept a clash of interests and redistribute power and resources from one side to the other."
However, the globe over, labour laws are now in a 'state of flux'. As new forms of employment like outsourcing, temping etc, come up, new issues pop up. Industrial laws are enacted to protect both employees and employers, and it is the responsibility of Human Resource managers to ensure that their respective organizations operate within the legal frameworks. However, many of these laws and standards are violated consistently, impacting significant labour force numbers. It usually is low-wage earners who experience violations, requiring setting up criteria for minimum wages, overtime work, and work during breaks. Consequently, leading to potential work safety issues (Järvis \& Tint, 2009).

Though many employees are familiar with the provisions of labour legislation, many are unaware of them. This unawareness can be attributed to the informational imbalance between employers and employees (Cabrelli, 2019). A practical solution to this problem is making employees aware of the provisions of labour laws. As an initial step towards this, there is a definite need to assess employees' awareness regarding labour laws. A fair review of the literature shows a paucity of tools to measure the understanding of labour laws.

The present study is an attempt to determine the understanding of Saudi Arabian labour laws among employees. As a member of ILO since 1976, Saudi Arabia has ratified 16 conventions (ILO, 1999). However, the Kingdom of Saudi Arabia ratified only six out of the eight basic conventions about fundamental labour rights. It is not a signatory to conventions like minimum age, freedom of association, and right to organize.

In Saudi Arabia, the constitution is derived from the Sharia. The primary labour production document is also derived from the Sharia (ILCCR, Examination of the individual case concerning Convention No. 100, 1994). Saudi labour law issued by the Royal Decree numbered M/51 of 2005 is bidimensional in nature. The law and its regulations consist of provisions about recruitment, employment (Saudi and expatriates), required qualifications, the working conditions, entering into and termination of contracts, disciplinary actions, termination from service, and certain other matters related to specific professions like seamen and miners. It also provides an astute dispute resolution framework in favour 
of the workers. It has provisions for fines and punishments for certain offences committed under the piece of legislation. Any explicit contractual agreement put across by employers in a contract with his employee that runs in contravention to the provisions of the law are not acceptable. However, there are doubts whether the Kingdom's workmen have the required awareness about the labour law provisions framed to protect them. The study's objectives are set in this backdrop. The study intends to examine this aspect. It is expected that the findings would be of immense significance academically and administratively to employers and administrators.

\section{Theoretical Background}

Law is a social construct and a 'system of systems' (Boer \& Engers, 2013, p. 68). Law presents a form of mechanism to influence behaviour, through encouraging desired and discouraging undesired behaviour. Law is highly dynamic and complex, and for it to be effective, it needs to be updated frequently in any modern society. Further, legal knowledge plays a cardinal role in deciding what a law seeks to do, as it often reasons for society's actions (Bolgár, 1967). This brings in the need to make the laws known to the people for whom they are intended. Empirical evidence suggests that, in general, people are ignorant of the laws that govern them (Rowell, 2019). This is true even for such laws which they consider important. Further, when people lack appropriate knowledge about law, they often get it wrong and develop distorted and unrealistic perceptions (Kahan \& Slovic, 2006; Tamanaha, 2018). According to Meager et al. (2002), knowledge is the 'theoretical or practical understanding of a subject'. Based on this definition, knowledge of employment legislation involves understanding the various provisions and is stronger than awareness.

Balcetis and Dunning (2006) opine that there is also the possibility of different individuals seeing laws differently based on personal knowledge, beliefs, values, and motivations. Substantial empirical works exist about how motivations make individuals misinterpret laws (Korobkin \& Ulen, 2000; Rowell, 2019; Tamanaha, 2018). The fact and people's views about laws have usually been found to be diametrically opposite, resulting in 'legal fantasy' (Rowell, 2019). They exhibit bounded rationality or willpower against rational self-interest (Korobkin \& Ulen, 2000). To avoid such fantasies and irrationalities, which are also prevalent in organizational settings, progressive organizations put in honest efforts to enhance employees' legal knowledge, in general, with particular emphasis on labour laws. Toward this, organizations put in their efforts to organize workshops and training programs for their members. These efforts need to get a fillip in Saudi organizations, as it lacks in the Kingdom, which has acted as a moving force behind this research.

However, many modest initiatives have been made in this direction by various administrative and legal bodies in the Kingdom. One such laudable effort is the Strategy Unit set up by ILO in the Ministry of Human Resource and Social Development 'to enhance its policy and strategy making capacity' (ILO, 2012). This unit intended to equip the Ministry to analyze the impact of economic and policy changes on the Saudi labour market. It is also designed to assist in the formulation of appropriate labour policies in the best interests of the various stakeholders of the country. The success of such efforts is based on knowing the awareness level of employees about labour laws. However, a fair literature review showed a paucity of an appropriate instrument to measure this knowledge.

Recently the discipline of labour laws has been subjected to repeated attacks from economists - particularly neo-classical economists (Brožová, 2015; Doering \& Piore, 1971). These attacks intensified with globalization and privatization competition, which created a severe competition that exerted pressure for framing less stringent labour market regulation. Attracting investment and preventing brain drain was the stated justification of this new thought process (Davidov, 2007). There are even scholars (e. g., Posner, 2007; Rubin, 1983) who contend that since common law has grown substantially and can sustain economic efficiency, there is no need for any special labour legislation. However, scholars of institutional economics and legal realism schools justified labour laws and considered them supportive (Akerlof \& Yellen, 1990; Davidov, 2007; Hoffman \& Averett, 2010; Kaufman, 2004, 2008; Manning, 2003). These scholars supported the view that regulations need to be made more attractive. Labour law and relations have 
multiple dimensions. They need to be sensitive to these various dimensions and deal with the redistribution of power and resources and the clash of interests of different stakeholders. Labour legislation protects the employees, prepares a level playing field, strives towards industrial democracy, and provides a just and humane environment (Budd, 2004; Kaufman, 2008; Dau-Schmidt, 1992). The body of labour legislation, in any country, includes a host of supplementing regulations. They could act as a correctional force against market failures (Davidov, 2007; Kaufman, 2008). This brings out the need for a fair understanding of labour laws by the employees.

Further, the famous adage that knowledge and the ability to control and access it are power. This statement is right in the employment context, in general, and employees in particular. Employer-employee relationships, the world over, are often marked by a certain number of informational imbalances. Employers often enjoy a higher level of expertise and access to labour markets and information and knowledge of the laws (Cabrelli, 2019; Kaufman, 1989). Employers hold a wealth of information about all aspects of employment, and at times they use it to the detriment of employees. Employees need to wield this power with awareness and purpose (Schoenbaum, 2011). Employees need to know their rights so that they are no exploited and abused by employers. If employees possess proper knowledge about labour laws, they will be better positioned to deal with their employers (Omar et al., 2009). Any asymmetric information on the employees' side will result in unanticipated consequences like employers taking undue advantages (Miceli, 2004). It has been found that the greater the knowledge about labour laws, the more confident will be the employees (Repa, 1994). However, many employees, including union members, are not aware of their rights enshrined in the labour laws (Omar et al., 2009).

Evidence shows that employers and employees rely on stereotypes despite an abundance of information, with heuristics forming the source for decisions. Thus, they make irrational decisions (bounded rationality) based on past experiences and a lack of awareness (Simon, 1978). In labour relations, there is the simultaneous existence of trust and mistrust, merger of interests and conflict of interests, rational and irrational behaviours, and inefficiencies along with efficiencies (Davidov, 2007). Therefore, there is a definite need for organizations to have employees with the required knowledge, skills, and competencies to do fair decision-making (Yean \& Yusof, 2016). This is all more important regarding the knowledge about labour laws. Legal knowledge acts to enhance labour rights. This can directly impact labour incentives (Che \& Zhang, 2017) and improve production and productivity (Deininger et al., 2008). Omar et al. (2009) undertook a study to identify the knowledge level of employees in Malaysia. The study found that respondents did not know their legal rights. However, they had a fair knowledge of their fundamental rights and had the slightest knowledge about termination.

Many provisions of labour laws like eligibility, entry and exit barriers, leaves, and notice periods primarily affect the employees, as employers have a significant say in these, which is attributable to employers' vast resources. Though each individual lives amid a broad network of various forms of legal rights and responsibilities, multiple studies have found low levels of legal literacy (Cabrelli, 2019). Pleasence and Balmer (2012) found legal literacy consistent with the issues' salience and legal education initiatives. Often, the stubbornness of employers poses significant challenges to education initiatives. The baseline of all labour education efforts needs to be the knowledge level of employees. Unfortunately, a sound testing instrument capable of assessing employees' knowledge levels of labour laws is missing. The present study is a modest attempt in this direction. Such a tool, it is presumed, would facilitate further empirical examination in this challenging area. It could also help to provide administrators with the required inputs needed to make required modifications or changes in the administration of labour laws.

\section{Research Methodology}

Several studies have provided the scientific process of developing empirically robust measurement tools (Clark \& Watson, 1995; Hinkin, 1998). The steps presented include item pool creation, administering questionnaires for collecting data, item reduction, and tool evaluation. In addition, Schwab (1980) and Hinkin (1998) provided a framework to develop empirically robust psychometric tools. The 
various stages presented by them are as follows: (1) item generation; (2) scale development; and (3) psychometric evaluation. This study has followed these frameworks and suggestions, which are presented in the following sections.

\subsection{Item Generation}

This stage consisted of creating an item pool, scaling and face validity, sample size, data collection, sampling, and item reduction.

First, the item pool should be created. Hinkin $(1995,1998)$ has provided detailed guidelines about the design of the item pool. This stage involved the identification of different domains of knowledge of labour laws. It also included a thorough review of the various provisions of the Saudi Labour Law. Proper domain sampling and parsimony would help achieve multiple validities (including content and construct validities) (Cronbach \& Meehl, 1955). The various domains identified in this study stage were General awareness, Health protection, Termination, and Working conditions. The next step involved determining the ideal number of items in each domain.

Hinkin (1995) and Nunnally (1978) note that too long or short scales could have adverse effects. According to pioneers like Anastasi (1976), Cook et al. (1981), and Schriesheim and Eisenbach (1991), a short-scale with a lesser number of items is ideal for dealing with the paucity of resources and time. It would also help in dealing effectively with biases arising out of respondent's boredom and fatigue. However, Hinkin (1995) and Nunnally (1978) cautions that fewer items could affect validities (content and construct), reliability, and internal consistency. According to Hinkin (1995), maintaining the appropriate scale length can reduce response bias, maintain a reasonably good domain sampling, and ensure internal consistency reliability.

For having a meaningful and fecund tool and comprehensive outlook about the construct, due care was exercised to keep the pool of items neither short long. The authors identified the initial items by reviewing related literature, analysing Saudi Labour Law, and discussing with experts in the field. These are absolute necessities for content validity (Bearden et al., 1993; Lopez-Fernandez et al., 2014; Tossell et al., 2015) and parsimony (Cronbach \& Meehl, 1955). The present study closely followed all these stipulations in developing the item pool.
The initial pool thus contained 20 items. After eliminating inconsistent, identical, and doublebarrelled items, the pool consisted of 17 items. A few items had to be rephrased to ensure accuracy.

Second, the scaling and face validity has to be performed. Since scaling provides the needed inputs for statistical analysis, there is a need to exercise the utmost care and caution in this stage. Further, the scale needs to generate an acceptable variance between the respondents (Hinkin, 1995). Scaling often has a range between 3 to 10 on Likert scales. According to Lissitz and Green (1975) and Nunnally (1978), Cronbach alpha increases typically up to 5 scales and subsequently levels off. Thus, a 5-point scale was used to have appropriate scaling.

In the next stage, the face value of the scale needs to be addressed. The capability to be understood, clear, and proper organization of the scale must obtain face validity (Sulphey \& Upadhyay, 2019; Sulphey, 2020; Swalih et al., 2019). All 17 items were arranged appropriately to ensure face validity.

Third, the sample size is a serious discussion among social scientists (Hinkin, 1995; Odeh \& Fox, 1991), as the appropriate size is essential for robust statistical tests and deriving reasonable statistical inferences (Hinkin, 1995; Lenth, 2001; Stone, 1978). The sample required for Factor Analysis (FA) is also a matter of academic discussion (Hoelter, 1993; Schwab, 1980; Viswanathan, 1993). The minimum samples suggested by Viswanathan (1993) and Hinkin (1995) were 100, and Hoelter (1993) 200. Schwab (1980) proposed an item-to-response ratio of $1: 10$, and Rummel (1970) 1:4. There is a need to exercise due care regarding sampling design to portray the population's essential characteristics accurately. The sample has to yield maximum precision with the minimum possible variance (Sulphey, 2020). All possible care and caution have been exercised to identify and select an appropriate sample in the present study.

Fourth, the description of data collection has to be provided. The researchers administered the 17-item questionnaire online (Google docs) and offline (questionnaires) to various gainfully employed Saudi Arabian workers. The willingness of the respondents was obtained before the data collection. The data collection process that lasted three months yielded 346 responses. 
Fifth, the sampling adequacy was examined in different ways. The first was using $G^{*}$ Power. The $G^{*} P o w e r$ analysis helps determine the sample size required to detect the effect of a particular size with a confidence level (Cohen, 1988; Kabacoff, 2017). Thus, to support the measurement models for each dependent with independent and control variables, the $\mathrm{G}^{*}$ Power analysis suggested a minimum sample size of 200 for a power of 0.80 and a significance level (alpha) of 0.05 (Faul et al., 2009).

The questionnaire was administered to 400 prospective respondents. Though 358 participants responded, only 346 were found usable. Twelve responses were rejected due to different reasons. The $G^{*} P o w e r$ analysis was used to assess if the sample is sufficient to support measurement models. The analysis using the $G^{*}$ Power sample size calculator (Faul et al., 2009) showed that to obtain a power of 0.80 and a significance level (alpha) of 0.05 , a minimum sample size of 200 is required. The collected data of 346 is thus well above the minimum sample size stipulated by $G^{*}$ Power analysis. The Kaiser-Meyer-Olkin and Bartlett's test (Kaiser, 1974) yielded a value of 0.817 . The chi-squared value of Bartlett's test of sphericity was 2,856.207, and the df was 136 , which is significant at 0.000 . The Bartlett's test of sphericity provides a significant measure of statistical probability that the correlation matrix has significant correlations among the factors and components. As the results were significant, $x^{2}(n=346)=2,856.207(P<0.001)$, which indicates the suitability for factor analysis (Williams et al., 2010). The Kaiser-MeyerOlkin (KMO) measure of sampling adequacy is an index used to examine the appropriateness of factor analysis. The KMO yielded a value of 0.817 , which shows that the proportion of variance for variables included in the study is the common variance. The high value of $\mathrm{KMO}$ indicates the appropriateness of the factor analysis for the data. The factor solution derived from this analysis yielded four factors (general awareness, working conditions, health protection, and termination), which accounted for $>70 \%$ of the variation in the data (Fabrigar et al., 2011). Besides, the present study met the stringent recommendation of Schwab (1980). As per his recommendation, there should be a minimum sample size of 170 . Further, the sample size of 346 is within Lenth's (2001) suggestion. Based on these, sample adequacy is assumed.

The demographic breakup of the data collected is presented in Tab. 1: 303 (87.6\%) were males and $43(12.4 \%)$ females. Even though the sample may seem disproportional the labour market in Saudi Arabia shows differences in comparison to Europe or USA due to cultural specifics. The minimum and

\section{Tab. 1: Sample demographics}

\begin{tabular}{l|l|c|c}
\multicolumn{2}{c|}{ Particulars } & Number & Percent \\
\hline \multirow{4}{*}{ Gender } & Male & 303 & 87.6 \\
\cline { 2 - 4 } & Female & 43 & 12.4 \\
\hline \multirow{4}{*}{ Marital status } & Married & 165 & 47.7 \\
\cline { 2 - 4 } & Unmarried & 268 & 48.6 \\
\cline { 2 - 4 } & Prefer not to say & 13 & 3.8 \\
\hline \multirow{3}{*}{ Qualification } & Saudi & 298 & 86.1 \\
\cline { 2 - 4 } & Expatriates & 48 & 13.9 \\
\hline \multirow{2}{*}{ Type of organization } & Junior school & 52 & 15.0 \\
\cline { 2 - 4 } & High school & 151 & 43.7 \\
\cline { 2 - 4 } & University & 143 & 41.3 \\
\cline { 2 - 4 } & Hospitality & 125 & 36.1 \\
\hline
\end{tabular}


maximum age of the respondents was 21 and 60 years, respectively. The average age of the respondents was 33.32 years. 165 $(47.7 \%)$ of the respondents were married, and $268(48.6 \%)$ were unmarried. The majority of the respondents were Saudi citizens (298 $86.1 \%)$. The type of organizations from which data collected includes a modern (technology) and a traditional (hospitality) type. 125 (36.1\%) samples belonged to the hospitality industry, and $221(63.9 \%)$ worked in the modern technology industry. Consequently, more males were involved since typically technology industry attracts more men to the job.

The sample's experience in the current organization ranged between 3 months and 38 years (mean 7.02), and the overall experience ranged from six months to 41 years (mean 10.05). There was also a wide diversity in terms of educational qualifications. These aspects point towards the diversity of the sample, which will aid in providing validity.

The sixth and last part of the item generation process is item reduction. The refining of the scale can be done using many techniques. A few of them include inter-item-correlations, item-tototal correlation, and factor analysis (FA) (Boyle, 1991; Hinkin, 1995, 1998). According to Boyle (1991), items can be eliminated through interitem-correlations. Items need to be eliminated if any inter-item correlation exceeds 0.70 . In the present study, no item warranted elimination, as none of the $r$ values exceeded 0.70 . In the next step, the item-to-total correlation was calculated. According to Kim and Mueller (1978) and Kumar and Beyerlein (1991), only those items having item-to-total correlation of over 0.40 are retained. The assumption behind this is that all items that belong to a common domain are bound to exhibit comparable average correlations. The $r$ values of item-to-total correlation are presented in Tab. 2. Lower r values, according to Churchill (1979), indicate that the items are not of the appropriate domain, resulting in questionable reliabilities. In the current case, all $r$ values are over 0.40 . Thus, no items need to be dropped.

\subsection{Scale Development}

Following item reduction, in this stage, Factor analysis (both exploratory and confirmatory) was conducted. The details of the factor analyses are presented in the following sections. After factor analysis, the reliability and validity of the scale were assessed. Tab. 3 shows the details of the exploratory factor analysis (EFA). The Principal component axis and Orthogonal (Varimax) rotation method with Kaiser Normalization were used for conducting EFA. Varimax rotation, which is an orthogonal rotation, has several interpretative advantages (Fabrigar et al., 1999; Wu, 2008). In varimax, the standardized variances are directly attributable to the extracted factors. It maximizes the variance of the squared loadings for each factor, thereby having a smaller number of large loadings (Abdi, 2003). This facilitates interpretative simplicity, as each variable is associated with one of the factors.

According to Ford et al. (1986) and Hinkin (1995), a factor loading of over 0.40 is mandatory for retaining an item. For the present study, all the factor loadings were above 0.40 (Tab. 3). Based on Eigenvalues, four factors emerged out of the EFA.

The first factor had five items, with an eigenvalue of 5.252. Based on the properties of the items, the factor was named 'General

\section{Tab. 2: Item-to-total correlation}

\begin{tabular}{c|c|c|c|c|c|c|c}
$\begin{array}{c}\text { Item } \\
\text { no. }\end{array}$ & $\begin{array}{c}\text { Item-to-total } \\
\text { correlation }\end{array}$ & $\begin{array}{c}\text { Item } \\
\text { no. }\end{array}$ & $\begin{array}{c}\text { Item-to-total } \\
\text { correlation }\end{array}$ & $\begin{array}{c}\text { Item } \\
\text { no. }\end{array}$ & $\begin{array}{c}\text { Item-to-total } \\
\text { correlation }\end{array}$ & $\begin{array}{c}\text { Item } \\
\text { no. }\end{array}$ & $\begin{array}{c}\text { Item-to-total } \\
\text { correlation }\end{array}$ \\
\hline $\mathbf{1}$ & $0.510^{* *}$ & $\mathbf{6}$ & $0.542^{* *}$ & $\mathbf{1 1}$ & $0.567^{* *}$ & $\mathbf{1 6}$ & $0.566^{* *}$ \\
\hline $\mathbf{2}$ & $0.440^{* *}$ & $\mathbf{7}$ & $0.537^{* *}$ & $\mathbf{1 2}$ & $0.639^{* *}$ & $\mathbf{1 7}$ & $0.538^{* *}$ \\
\hline $\mathbf{3}$ & $0.524^{* *}$ & $\mathbf{8}$ & $0.436^{* *}$ & $\mathbf{1 3}$ & $0.641^{* *}$ & & \\
\hline $\mathbf{4}$ & $0.575^{* *}$ & $\mathbf{9}$ & $0.500^{* *}$ & $\mathbf{1 4}$ & $0.580^{* *}$ & & \\
\hline $\mathbf{5}$ & $0.575^{* *}$ & $\mathbf{1 0}$ & $0.563^{* *}$ & $\mathbf{1 5}$ & $0.480^{* *}$ & & \\
\hline
\end{tabular}




\section{Exploratory factor rotation matrix}

Rotated Component Matrix

\begin{tabular}{|c|c|c|c|c|c|}
\hline \multirow{2}{*}{$\begin{array}{c}\text { Item } \\
\text { number }\end{array}$} & \multicolumn{4}{|c|}{ Component } & \multirow[b]{2}{*}{ Communalities } \\
\hline & $\begin{array}{c}\text { General } \\
\text { awareness }\end{array}$ & $\begin{array}{l}\text { Working } \\
\text { conditions }\end{array}$ & $\begin{array}{c}\text { Health } \\
\text { protection }\end{array}$ & Termination & \\
\hline GA 1 & 0.879 & & & & 0.783 \\
\hline GA 2 & 0.852 & & & & 0.775 \\
\hline GA 3 & 0.753 & & & & 0.684 \\
\hline GA 4 & 0.694 & & & & 0.556 \\
\hline GA 5 & 0.677 & & & & 0.592 \\
\hline HP1 & & & 0.602 & & 0.671 \\
\hline HP2 & & & 0.762 & & 0.624 \\
\hline HP3 & & & 0.679 & & 0.651 \\
\hline TE1 & & & & 0.512 & 0.750 \\
\hline TE2 & & & & 0.840 & 0.705 \\
\hline TE3 & & & & 0.791 & 0.592 \\
\hline WC1 & & 0.611 & & & 0.700 \\
\hline WC2 & & 0.747 & & & 0.679 \\
\hline WC3 & & 0.743 & & & 0.600 \\
\hline WC4 & & 0.708 & & & 0.583 \\
\hline WC5 & & 0.682 & & & 0.653 \\
\hline WC6 & & 0.702 & & & 0.613 \\
\hline
\end{tabular}

Extraction Method: Principal Component Analysis.

Rotation Method: Varimax with Kaiser Normalization.

a. Rotation converged in 7 iterations.

\section{Tab. 4: Fit indices of the model}

\begin{tabular}{l|c|c|l}
\multicolumn{1}{c|}{ Fit index } & $\begin{array}{c}\text { Final model } \\
\text { value }\end{array}$ & $\begin{array}{c}\text { Cut-off for } \\
\text { good fit }\end{array}$ & \multicolumn{1}{|c}{ Reference } \\
\hline $\begin{array}{l}\text { Root mean square error } \\
\text { of approximation (RMSEA) }\end{array}$ & 0.041 & $<0.07$ & Steiger, 2007 \\
\hline Comparative fit index (CFI) & 0.981 & $>0.90$ & Bentler, 1990 \\
\hline Normed fit index (NFI) & 0.971 & $>0.80$ & Hooper et al., 2008 \\
\hline Root mean square residual (RMSR) & 0.038 & $<0.05$ & $\begin{array}{l}\text { Byrne, 1998; Diamantopoulos } \\
\text { \& Siguaw, 2000 }\end{array}$ \\
\hline Parsimony goodness of fit index (PGFI) & $\begin{array}{l}0.814 \\
\text { near 0.50 }\end{array}$ & Kelloway, 1998 \\
\hline Tucker Lewis index (TLI) & $\begin{array}{c}0.919 \\
>0.90\end{array}$ & Bentler \& Bonnett, 1980 \\
\hline Coefficient alpha & $\begin{array}{c}0.774 \text { to } \\
0.819\end{array}$ & $>0.70$ & Nunnally, 1978 \\
\hline
\end{tabular}




\section{Business Administration and Management}

awareness'. The second factor consisting of three items had an eigenvalue of 2.018. This factor had items about the information about the termination from services and was hence cherished 'Termination'. The third factor, named 'Health protection', has three items with an eigenvalue of 1.078. The fourth factor has six items (an eigenvalue of 2.866). This factor was named 'Working conditions'. After EFA, Confirmatory Factor Analysis (CFA) was conducted.

Confirmatory factor analysis (CFA) was done using the $\mathrm{R}$ program. CFA helps confirm the factor structure and judge the model's level of significance (Kaur \& Sharma, 2015). Tab. 4 presents the fit index of the CFA.
Tab. 4 shows that all the fit indices' model values are well within the thump rules. Thus, all the indexes can be considered acceptable and superior, indicating a perfect fit. The measurement model is presented in Fig. 1. The model shows the higher causal relationship between the factor (knowledge of labour law), the subfactors (TE, HP, WC, and GA) and items. The modelling was performed to check the validity of items and constructs in the proposed research model. Based on reliability and validity measures and factor loadings, the final measurement model was arrived at. All the paths were having robust loadings, as can be observed from the Fig. 1.

\section{Fig. 1: Measurement model}

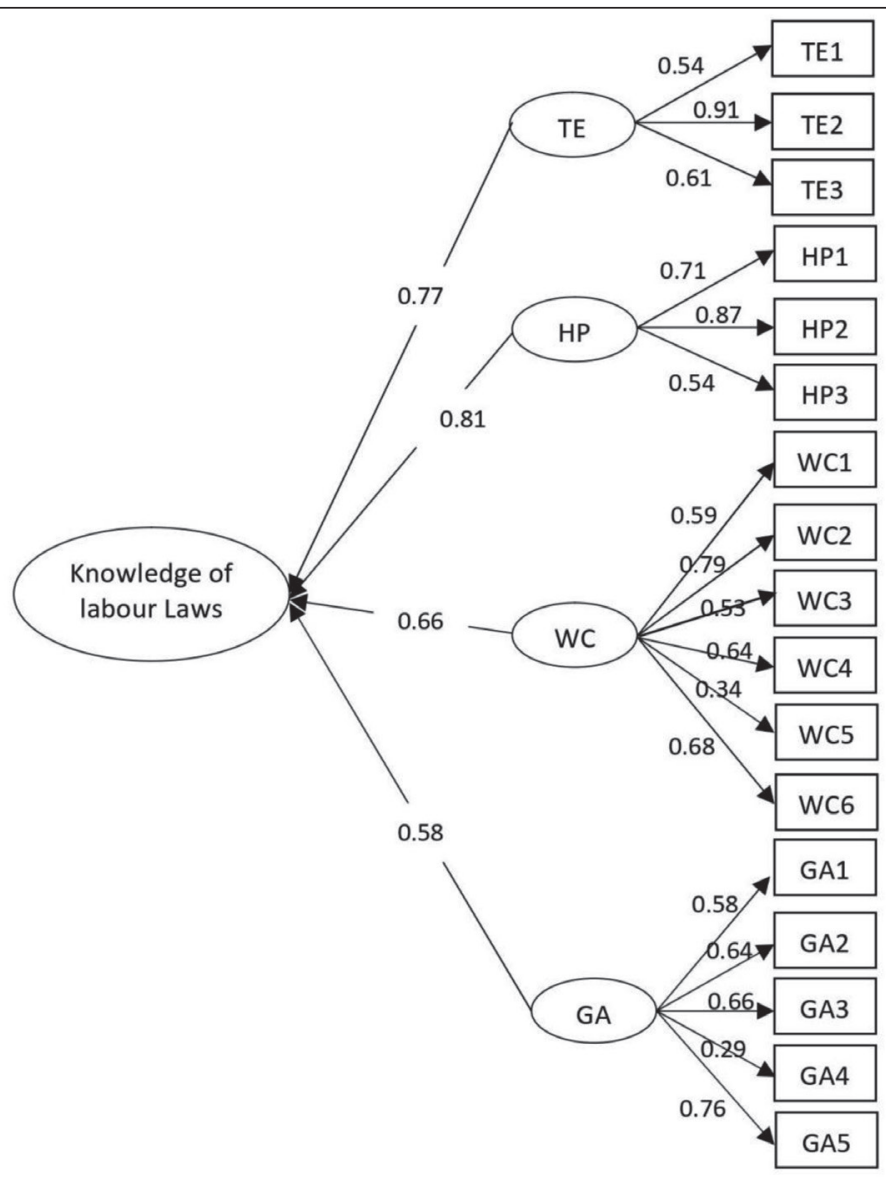




\subsection{Psychometric Evaluation}

The internal consistency reliability was assessed using Cronbach's alpha and item-tototal correlations (Tab. 5). All the alpha values are above 0.70 , as per Nunnally's (1978) suggestion (the lowest was 0.811 and the highest 0.875 ). This shows that the model's internal consistency reliability is met (Raes et al., 2010).

The next step in our analysis is estimation of validities. The validities typically assessed include content, convergent, discriminant, and criterion. According to Stone (1978), content validity is "the degree to which an instrument covers the meaning of the concepts included in a particular research". Unfortunately, there is a lack of an acceptable quantitative index for content validity. Validation is done through the exercise of investigator judgment (Stone, 1978). As the current instrument was constructed based on an extensive literature review and subsequent refinements and validation, content validity can be assumed. Convergent validity occurs if evidence for the study is gathered from multiple sources (Kerlinger, 1992). In creating the item pool, an inductive approach was adopted with the utmost care and caution. The items were thus identified after an extensive literature review.

The AVE and item loadings are considered to assess the model's convergent validity (Hair et al., 2013). The AVE's thumb rule is that the values need to be over 0.50 (Hair et al., 2013; Barclay et al., 1995). Composite reliability (CR) measures the overall reliability of the items. According to Hair et al. (2014), the minimum value of $C R$ needs to be 0.70 . Tab. 6 presents the details of AVE and CR. It can be seen that all the AVE and CR values are well above the stipulated limits. This shows that the instrument has convergent validity.

Discriminant validity is the extent to which the measures or constructs are distinctive from the other and share variances among themselves within the model (Hulland, 1999). It evidences the uniqueness of a construct (Hair et al., 2013). If there is a relatively low correlation between the factors, discriminant validity is assumed (Bagozzi \& Kimmel, 1995). Further, the loadings of variables under

\section{Tab. 5: Reliability measures of the model}

\begin{tabular}{|c|c|c|c|c|c|}
\hline Construct & Item & EFA & $\begin{array}{l}\text { Factor loadings } \\
\text { for CFA }\end{array}$ & $\begin{array}{l}\text { Item to total } \\
\text { correlation }\end{array}$ & $\begin{array}{l}\text { Reliability measure } \\
\text { (Cronbach's alpha) }\end{array}$ \\
\hline \multirow{5}{*}{$\begin{array}{l}\text { General } \\
\text { awareness }\end{array}$} & GA1 & 0.879 & 0.876 & 0.712 & \multirow{5}{*}{0.845} \\
\hline & GA2 & 0.852 & 0.852 & 0.811 & \\
\hline & GA3 & 0.753 & 0.754 & 0.759 & \\
\hline & GA4 & 0.694 & 0.695 & 0.756 & \\
\hline & GA5 & 0.677 & 0.676 & 0.789 & \\
\hline \multirow{3}{*}{$\begin{array}{l}\text { Health } \\
\text { protection }\end{array}$} & HP1 & 0.602 & 0.608 & 0.741 & \multirow{3}{*}{0.811} \\
\hline & HP2 & 0.762 & 0.767 & 0.859 & \\
\hline & HP3 & 0.679 & 0.773 & 0.862 & \\
\hline \multirow{3}{*}{ Termination } & TE1 & 0.512 & 0.516 & 0.845 & \multirow{3}{*}{0.862} \\
\hline & TE2 & 0.840 & 0.847 & 0.745 & \\
\hline & TE3 & 0.791 & 0.795 & 0.722 & \\
\hline \multirow{6}{*}{$\begin{array}{l}\text { Working } \\
\text { conditions }\end{array}$} & WC1 & 0.611 & 0.711 & 0.789 & \multirow{6}{*}{0.875} \\
\hline & WC2 & 0.747 & 0.746 & 0.852 & \\
\hline & WC3 & 0.743 & 0.747 & 0.915 & \\
\hline & WC4 & 0.708 & 0.708 & 0.856 & \\
\hline & WC5 & 0.682 & 0.711 & 0.842 & \\
\hline & WC6 & 0.702 & 0.707 & 0.826 & \\
\hline
\end{tabular}




\section{Business Administration and Management}

Tab. 6: Convergent validity (AVE and CR)

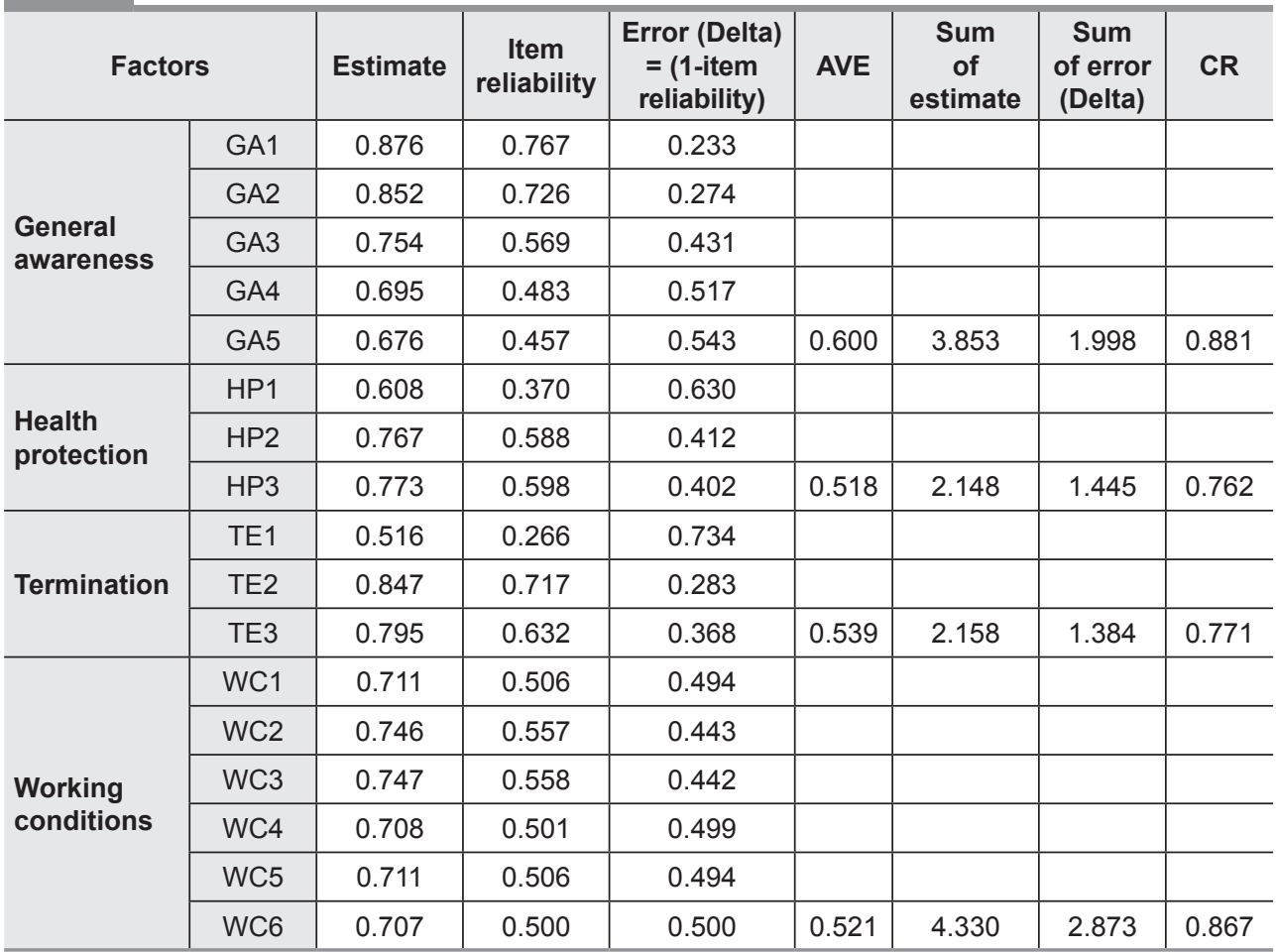

a particular latent variable need to be higher than the other latent variables. The details of the discriminant validity are presented in Tab. 7 . It can be observed that no factor has an $r$ value greater than 0.70 (Anderson \& Gerbing, 1988), and the values are lesser than the square roots of AVE (the diagonal values), thereby meeting the stipulation of Fornell and Larcker (1981) regarding discriminant validity.
A measurement instrument also needs to enjoy construct validity. It is the extent to which a scale measures what it needs to measure (Hinkin, 1998). Construct validity can be considered the link between the respective theory and the psychometric properties (Kerlinger, 1986). Any measure is categorized as robust and has quality only if it demonstrates appropriate construct validity (Cronbach \&

\section{Tab. 7: Discriminant validity}

\begin{tabular}{l|c|c|c|c}
\multicolumn{1}{c|}{ Factors } & $\begin{array}{c}\text { General } \\
\text { awareness }\end{array}$ & $\begin{array}{c}\text { Health } \\
\text { protection }\end{array}$ & Termination & $\begin{array}{c}\text { Working } \\
\text { conditions }\end{array}$ \\
\hline General awareness & $\mathbf{0 . 7 4 1}$ & & & \\
\hline Health protection & 0.311 & $\mathbf{0 . 8 4 1}$ & & \\
\hline Termination & 0.265 & 0.026 & $\mathbf{0 . 7 5 6}$ & \\
\hline Working conditions & 0.154 & 0.115 & 0.124 & $\mathbf{0 . 7 5 9}$ \\
\hline
\end{tabular}


Meehil, 1955; Schmitt \& Klimoski, 1991). A measuring instrument has construct validity when it demonstrates internal consistency and content validities (Hinkin, 1998). This measuring instrument enjoys construct validity as it showed internal consistency, constancy, and all other required validities. However, it would be better if further refining of the measure is done in the future. The authors will be obliged if further examinations are done in this direction.

Having generalized and validated the questionnaire, an attempt was made to assess the level of labour law knowledge among the different types of employees. The knowledge of employees, based on certain demographics, was also attempted. The demographics attempted were gender, nationality, type of organization, and qualification levels. T-test and ANOVA were used to find out the possible existence of any difference between the samples. Assumptions of t-test and ANOVA were checked using normality and homogeneity (Park, 2015). Normality measures the data in respect of all the items in the knowledge of labour law factors easily pass the normality test as the skewness value is in the range of +1 to -1 and the value of kurtosis ranges between +3 and -3 . Hence all the items are normally distributed. The Levene statistic is not significant for all the items included in the factors. It is thus confirmed from those values that the homogeneity among the data is absent

\section{Tab. 8: Results of t-test based on gender}

\begin{tabular}{|c|c|c|c|c|c|}
\hline & Gender & $\mathbf{N}$ & Mean & Std. dev. & t-value \\
\hline \multirow{2}{*}{ General awareness } & Male & 303 & 11.613 & 3.7650 & \multirow{2}{*}{1.732} \\
\hline & Female & 43 & 10.561 & 2.5695 & \\
\hline \multirow{2}{*}{ Health protection } & Male & 303 & 16.310 & 4.5217 & \multirow{2}{*}{$2.290^{*}$} \\
\hline & Female & 43 & 14.634 & 3.2308 & \\
\hline \multirow{2}{*}{ Termination } & Male & 303 & 7.801 & 2.1448 & \multirow{2}{*}{1.417} \\
\hline & Female & 43 & 7.293 & 2.1937 & \\
\hline \multirow{2}{*}{ Working condition } & Male & 303 & 7.690 & 2.5512 & \multirow{2}{*}{1.310} \\
\hline & Female & 43 & 7.146 & 1.9437 & \\
\hline \multirow{2}{*}{ Overall knowledge } & Male & 303 & 43.415 & 8.980 & \multirow{2}{*}{$2.585^{*}$} \\
\hline & Female & 43 & 39.634 & 6.963 & \\
\hline
\end{tabular}

Source: own

Note: * significant at 0.05 level.

(Baarda et al., 2019). Thus, the data is ideal for further statistical analysis. The details are presented in the following sections.

It can be seen from Tab. 8 that based on gender, there is a significant difference at 0.05 level $(t=2.585)$. The mean and SD for males was higher at 43.415 and 8.980 . This denotes males have a better level of knowledge about labour laws than females. In the factor-wise comparison, only 'Health protection' had a significant difference, with the other three factors not exhibiting any difference.

A t-test was also conducted to determine the difference between Saudi citizens and expatriates regarding their knowledge of labour laws. The results show that there is a significant difference between Saudis and expatriates $(t=4.388)$. Furthermore, examining the mean values shows that expatriate employees (48.826) have better knowledge about labour laws than their Saudi counterparts (42.532).

Significant differences were also observed in all four factors (Tab. 9). Thus, the reason for expatriates having better knowledge could be because most of them are involved in higherend skilled jobs and are intellectually better off. Further, the government's recent Saudization efforts have reduced expatriates in middleorder and semi-skilled jobs. 


\section{Business Administration and Management}

\section{Tab. 9:}

\section{Results of t-test based on nationality}

\begin{tabular}{l|l|r|r|r|c}
\multicolumn{1}{c|}{ Factors } & Nationality & $\mathbf{N}$ & Mean & Std. dev. & \multirow{2}{*}{ t-value } \\
\hline \multirow{2}{*}{ General awareness } & Saudi & 298 & 11.854 & 3.6534 & \multirow{2}{*}{$2.353^{*}$} \\
\cline { 2 - 5 } & Expatriate & 48 & 10.457 & 4.2932 & \\
\hline \multirow{2}{*}{ Health protection } & Saudi & 298 & 15.786 & 4.4620 & \multirow{2}{*}{$4.317^{\star *}$} \\
\cline { 2 - 5 } & Expatriate & 48 & 18.978 & 5.8099 & \\
\hline \multirow{2}{*}{ Termination } & Saudi & 298 & 7.639 & 2.1606 & \multirow{2}{*}{$3.629^{* *}$} \\
\cline { 2 - 5 } & Expatriate & 48 & 8.870 & 1.9845 & \\
\hline \multirow{2}{*}{ Working condition } & Saudi & 298 & 7.252 & 2.1807 & \multirow{2}{*}{$9.199^{* *}$} \\
\cline { 2 - 5 } & Expatriate & 48 & 10.522 & 2.6055 & \\
\hline \multirow{2}{*}{ Overall knowledge } & Saudi & 298 & 42.531 & 9.0632 & \multirow{2}{*}{$4.388^{* *}$} \\
\cline { 2 - 5 } & Expatriate & 48 & 48.826 & 8.9525 & \\
\hline
\end{tabular}

Source: own

Note: * significant at 0.05 level; ${ }^{* *}$ significant at 0.01 level.

\section{Tab. 10: Results of t-test based on types of organization}

\begin{tabular}{|c|c|c|c|c|c|}
\hline Factors & Industry & $\mathbf{N}$ & Mean & Std. dev. & $\mathrm{t}$-value \\
\hline \multirow{2}{*}{ General awareness } & Hospitality & 125 & 11.160 & 2.164 & \multirow{2}{*}{1.920} \\
\hline & Technology & 221 & 11.964 & 4.386 & \\
\hline \multirow{2}{*}{ Health protection } & Hospitality & 125 & 14.416 & 2.680 & \multirow{2}{*}{$5.425^{\star *}$} \\
\hline & Technology & 221 & 17.190 & 5.348 & \\
\hline \multirow{2}{*}{ Termination } & Hospitality & 125 & 7.120 & 1.654 & \multirow{2}{*}{$4.570^{* *}$} \\
\hline & Technology & 221 & 8.213 & 2.366 & \\
\hline \multirow{2}{*}{ Working condition } & Hospitality & 125 & 7.064 & 1.554 & \multirow{2}{*}{$3.627^{* *}$} \\
\hline & Technology & 221 & 8.068 & 2.864 & \\
\hline \multirow{2}{*}{ Overall knowledge } & Hospitality & 125 & 39.760 & 6.120 & \multirow{2}{*}{$5.706^{*}$} \\
\hline & Technology & 221 & 45.434 & 10.116 & \\
\hline
\end{tabular}

Note: * significant at 0.05 level; ${ }^{* *}$ significant at 0.01 level.

Tab. 10 shows a significant difference between employees based on the type of industry they work in $(t=5.706)$. The knowledge level of employees in technology (mean $=45.434)$ was higher than that of the hospitality employees (mean $=39.760$ ). A similar uniform pattern was evident in all the factors. This is on expected lines, as technology employees are better qualified and have better access to information than the hospitality industry employees.
ANOVA was done to find out if there existed any difference based on the qualifications of the respondents. The results are presented in Tab. 11.

Tab. 11 shows a significant difference at the 0.01 level based on the respondents' qualifications $(F=13.649)$. Other than general awareness, all the factors exhibited this trend. Naturally, those respondents with higher qualifications are likely to have better knowledge about labour laws, which is evident from the results. 
Tab. 11: Results of ANOVA based on qualifications

\begin{tabular}{|c|c|c|c|c|c|c|}
\hline \multicolumn{7}{|c|}{ ANOVA } \\
\hline & & Sum of squares & df & Mean square & $\mathbf{F}$ & Sig. \\
\hline \multirow{3}{*}{$\begin{array}{l}\text { General } \\
\text { awareness }\end{array}$} & Between groups & 41.853 & 2 & 20.927 & 1.480 & 0.229 \\
\hline & Within groups & $4,424.738$ & 313 & 14.137 & & \\
\hline & Total & $4,466.592$ & 315 & & & \\
\hline \multirow{3}{*}{$\begin{array}{l}\text { Health } \\
\text { protection }\end{array}$} & Between groups & 675.004 & 2 & 337.502 & 16.776 & 0.000 \\
\hline & Within groups & $6,297.005$ & 313 & 20.118 & & \\
\hline & Total & $6,972.009$ & 315 & & & \\
\hline \multirow{3}{*}{ Termination } & Between groups & 82.361 & 2 & 41.181 & 8.944 & 0.000 \\
\hline & Within groups & $1,441.082$ & 313 & 4.604 & & \\
\hline & Total & $1,523.443$ & 315 & & & \\
\hline \multirow{3}{*}{$\begin{array}{l}\text { Working } \\
\text { condition }\end{array}$} & Between groups & 47.791 & 2 & 23.896 & 3.971 & 0.020 \\
\hline & Within groups & $1,883.386$ & 313 & 6.017 & & \\
\hline & Total & $1,931.177$ & 315 & & & \\
\hline \multirow{3}{*}{ Total } & Between groups & $2,276.759$ & 2 & $1,138.380$ & 13.649 & 0.000 \\
\hline & Within groups & $26,106.102$ & 313 & 83.406 & & \\
\hline & Total & $28,382.861$ & 315 & & & \\
\hline
\end{tabular}

Source: own

Note: * significant at 0.05 level; ** significant at 0.01 level.

\section{Research Results}

Employers have the right, power, and authority to have command over employees, and their capacity to make unilateral decisions concerning workplace affairs confers on them significant powers. Unfortunately, such capabilities are, at times, abused by employers. This is why inequality in employer-employee relations and the need for labour laws exist (Davidov, 2007). Though there are multiple labour laws intended to protect the labour force's rights and bring harmony in the workplace, the knowledge imbalance is causing problems the world over. However, there is a lack of robust empirical evidence about legal knowledge among people (Rowell, 2019). Casebourne et al. (2006) suggested that employee education would help them to learn about their rights.

The study's objective was to develop, standardize, and validate a scale to measure employees' knowledge of labour laws. Based on Saudi Arabia's labour law and literature review, an initial pool of 17 items was arrived at. Then, the researchers did scale purification with different techniques like inter-item correlation, item-to-total correlation, EFA and CFA, and the like. All the reliability and validity statistics show robust fits. Thus, the study succeeded in constructing and validating a multi-dimensional measurement tool capable of assessing labour law knowledge levels among employees. These dimensions are General Awareness, Health Protection, Termination and Working Conditions.

Only scant empirical evidence exists in the literature regarding the labour law measurement tool. This is one of the first attempts to construct and validate a questionnaire to measure the employees' knowledge about labour laws. The questionnaire is ideal for further empirical examination in this exciting area. It is expected that more research would be conducted using this questionnaire. The study also examined the differences in the knowledge level of labour laws based on demographics. The results show a significant difference between the knowledge levels based on gender, citizenship, type of industry, and 
qualifications. However, there is evidence to show that demographics can influence several behavioural elements. An earlier study by Omar et al. (2009) examined the difference in the familiarity of banking employees with labour laws based on demographics like gender, age, experience, and qualification levels. They found that the respondents lacked sound knowledge about their legal rights. Further, they found differences in knowledge levels based on gender. Experience and education levels also influenced the level of knowledge. The current study thus substantiates this finding. The finding that women have better knowledge about labor laws aligns with Meager et al.'s (2002) findings. They found women to have higher levels of knowledge about employment rights. They also found that though women have better knowledge, men acted with informed awareness. This study also found a difference in knowledge based on ethnic origin. However, they failed to find any pattern based on the qualifications of the respondents. Contrary to this, the present study found a significant difference in knowledge based on qualifications. The findings of nationality and type of organization can be considered as fresh additions to the literature leaving policymakers with better understanding of differences among industries. There is a definite need to have more empirical examinations to substantiate the study's findings.

In general, knowledge about labour laws would facilitate compliance with legislation and prompt employees to work together to create a fair, safe, healthy, and progressive work atmosphere. This would help in achieving the economic and social goals of organizations and the country.

\section{Conclusions}

With the present study and the supporting empirical data, a tool to examine employees' labour law knowledge was constructed. The research has also helped in shedding fresh light on the knowledge pattern of labour laws. One of the limitations of the present study is that it has been limited to samples from Saudi Arabia. Though the samples were collected from Saudi Arabia, the items are so constructed to be universally applicable. Further research could be undertaken in other locations using the same instrument or a modified version to assess its general applicability. Future researchers can also conduct another study using a broader cross-section of samples to validate the questionnaire further. It is expected that, in addition to triggering further studies in this area, the developed tool would be further refined by researchers and scholars. The authors of the paper would be highly obliged if further literature is added using this questionnaire.

\section{References}

Abdi, H. (2003). Factor Rotations in Factor Analyses. In M. Lewis-Beck, A. Bryman, \& T. Futing (Eds.), Encyclopedia of Social Sciences Research Methods. Thousand Oaks, CA: Sage.

Akerlof, G. A., \& Yellen, J. L. (1990). The Fair Wage-Effort Hypothesis and Unemployment. Quarterly Journal of Economics, 105(2), 255283. https://doi.org/10.2307/2937787

Anastasi, A. (1976). Psychological Testing (4th ed.). New York, NY: Macmillan.

Anderson, J. C., \& Gerbing, D. W. (1988). Structural equation modeling in practice: A review and recommended two-step approach. Psychological Bulletin, 103(3), 411-423. https:// doi.org/10.1037/0033-2909.103.3.411

Baarda, D. B., de Goede, M. P., \& Van Dijkum, C. J. (2019). Milton Park: Routledge.

Bagozzi, R. P., \& Kimmel, S. K. (1995). A comparison of leading theories for the prediction of goal-directed behaviours. British Journal of Social Psychology, 34(4), 437-461. https://doi.org/10.1111/j.2044-8309.1995. tb01076.x

Balcetis, E., \& Dunning, D. (2006). See what you want to see: Motivational influences on visual perception. Journal of Personality and Social Psychology, 91(4), 612-625. https://doi. org/10.1037/0022-3514.91.4.612

Barclay, D. W., Higgins, C. A., \& Thompson, R. (1995). The partial least squares approach to causal modelling: personal computer adoption and use as illustration. Technology Studies, 2, 285-309.

Bearden, W. O., Netemeyer, R. G., \& Mobley, M. F. (1993). Handbook of Marketing Scales. Newbury Park, CA: SAGE Publications. https://doi.org/10.4135/9781412996761

Bellou, V., Chaniotakis, I., Kehagias, I., \& Rigopoulou, I. (2015). Employer Brand of Choice: An Employee Perspective. Journal of Business Economics and Management, 16(6), 1201-1215. https://doi.org/10.3846/16111699.2013.84822

Bentler, P. M. (1990). Comparative fit indexes in structural models. Psychological 
Bulletin, 107(2), 238-246. https://doi. org/10.1037/0033-2909.107.2.238

Bentler, P. M., \& Bonett, D. G. (1980). Significance tests and goodness-of-fit in the analysis of covariance structures. Psychological Bulletin, 88(3), 588-600. https:// doi.org/10.1037/0033-2909.88.3.588

Boer, A., \& Engers, T. V. (2013). Legal knowledge and agility in public administration, Intelligent Systems in Accounting, Finance and Management, 20(2), 67-88. https://doi. org/10.1002/isaf.1339

Bolgár, V. (1967). The Present Function of the Maxim Ignorantia luris Neminem Excusat - A Comparative Study. lowa Law Review, 52, 626-627.

Boyle, G. J. (1991). Does item homogeneity indicate internal inconsistency or item redundancy in psychometric scales? Personality and Individual Differences, 12(3), 291-294. https://doi.org/10.1016/0191-8869(91)90115-R

Brožová, D. (2015). Modern labour economics: the neoclassical paradigm with institutional content. Procedia Economics and Finance, 30, 50-56. https://doi.org/10.1016/ S2212-5671(15)01254-X

Budd, J. (2004). Employment with a Human Face: Balancing Efficiency, Equity and Voice. Ithaca, NY: Cornell University Press. https://doi. org/10.7591/9781501722387

Byrne, B. M. (1998). Structural Equation Modeling with LISREL, PRELIS and SIMPLIS: Basic Concepts, Applications and Programming. Mahwah, NJ: Lawrence Erlbaum Associates. https://doi.org/10.4324/9780203774762

Cabrelli, D. (2019). The role of standards of review in labour law. Oxford Journal of Legal Studies, 39(2), 374-403. https://doi. org/10.1093/ojls/gqz006

Casebourne, J., Regan, J., Neathey, F., \& Tuohy, S. (2006). Employment Rights at Work: Survey of Employees 2005 (Employment Relations Research Series No. 51). London: Department of Trade and Industry, Institute of Employment Studies.

Che, Y., \& Zhang, Y. (2017). Legal Knowledge, Land Expropriation, and Agricultural Development in Rural China. Frontiers of Economics in China, 12(1), 132-166. https:// doi.org/10.3868/s060-006-017-0007-1

Churchill, G. A. (1979). A Paradigm for Developing Better Measures for Marketing Constructs. Journal of Marketing Research, 16(1), 64-73. https://doi.org/10.2307/3150876
Clark, L. A., \& Watson, D. (1995). Constructing validity: Basic issues in objective scale development. Psychological Assessment, 7(3), 309-319. https://doi.org/10.1037/10403590.7.3.309

Cohen, J. (1988). Statistical Power Analysis for the Behavioral Sciences (2nd ed.). New York, NY: Routledge. https://doi. org/10.4324/9780203771587

Cook, J. D., Hepworth, S. J., Wall, T. D., \& Warr, P. B. (1981). The Experience of Work. London: Academic Press.

Cronbach, L. J., \& Meehil, P. C. (1955). Construct validity in psychological tests. Psychological Bulletin, 52(4), 281-302. https:// doi.org/10.1037/h0040957

Dau-Schmidt, K. (1992). A Bargaining Analysis of American Labor Law and the Search for Industrial Peace. Michigan Law Review, 91(3), 419-514.

Davidov, G. (2007). The (changing?) idea of labour law. International Labour Review, 146(3-4), 311-320. https://doi.org/10.1111/ j.1564-913X.2007.00017.x

Deakin, S. (2012). The law and economics of employment protection legislation. In C. L. Estlund, \& M. L. Wachter (Eds.), Research Handbook on the Economics of Labor and Employment Law (pp. 330-356). Cheltenham: Edward Elgar Publishing.

Deininger, K., Ali, D. A., \& Yamano, T. (2008). Legal knowledge and economic development: The case of land rights in Uganda. Land Economics, 84(4), 593-619.

Diamantopoulos, A., \& Siguaw, J. A. (2000). Introducing LISREL: A Guide for the Uninitiated. London: Sage Publications.

Doeringer, P. B., \& Piore, M. J. (1985). Internal Labor Markets and Manpower Analysis. Cambridge, MA: Harvard University.

Eger, L., Mičík, M., Gangur, M., \& Řehoř, P. (2019). Employer Branding: Exploring Attractiveness Dimensions in a Multicultural Context. Technological and Economic Development of Economy, 25(3), 519-541. https://doi.org/10.3846/tede.2019.9387

Fabrigar, L. R., \& Wegener, D. T. (2011). Exploratory Factor Analysis. Oxford: Oxford University Press.

Fabrigar, L. R., Wegener, D. T., MacCallum, R. C., \& Strahan, E. J. (1999). Evaluating the use of exploratory factor analysis in psychological research. Psychological Methods, 4(3), 272299. https://doi.org/10.1037/1082-989X.4.3.272 
Faul, F., Erdfelder, E., Buchner, A., \& Lang, A.-G. (2009). Statistical power analyses using $G^{*}$ Power 3.1: Tests for correlation and regression analyses. Behavior Research Methods, 41(4), 1149-1160. https://doi. org/10.3758/BRM.41.4.1149

Ford, J. K., MacCallum, R. C., \& Tait, M. (1986). The application of exploratory factor analysis in applied psychology: A critical review and analysis. PersonnelPsychology, 39(2), 291314. https://doi.org/10.1111/j.1744-6570.1986. tb00583.x

Fornell, C., \& Larcker, D. F. (1981). Structural equation models with unobservable variables and measurement error: Algebra and statistics. Journal of Marketing Research, 18(3), 382. https://doi.org/10.2307/3150980

Hair Jr, F. J., Sarstedt, M., Hopkins, L., \& Kuppelwieser, V. G. (2014). Partial least squares structural equation modeling (PLSSEM). European Business Review, 26(2), 106121. https://doi.org/10.1108/ebr-10-2013-0128

Hair, J. F., Ringle, C. M., \& Sarstedt, M. (2013). Partial Least Squares Structural Equation Modeling: Rigorous Applications, Better Results and Higher Acceptance. Long Range Planning, 46(1-2), 1-12. https://doi. org/10.1016/j.Irp.2013.01.001

Hinkin, T. R. (1995). A Review of Scale Development Practices in the Study of Organizations. Journal of Management, 21(5), 967-988. https://doi.org/10.1016/01492063(95)90050-0

Hinkin, T. R. (1998). A Brief Tutorial on the Development of Measures for Use in Survey Questionnaires. Organizational Research Methods, 1(1), 104-121. https://doi. org/10.1177/109442819800100106

Hoelter, J. W. (1993). The Analysis of CovarianceStructures: Goodness-of-Fit Indices. Sociological Methods and Research, 11(3), 325-344. https:// doi.org/10.1177/0049124183011003003

Hoffman, S. D., \& Averett, S. L. (2010). Women and the Economy. Family, Work, and Pay (2nd ed.). Boston, MA: Pearson, AddisonWesley.

Hooper, D., Coughlan, J., \& Mullen, M. (2008). Structural equation modelling: guidelines for determining model fit. Electronic Journal of Business Research Methods, 6(1), 53-60. https://doi.org/10.21427/D7CF7R

Hulland, J. (1999). Use of Partial Least Squares (PLS) in Strategic Management Research: A Review of Four Recent Studies.
Strategic Management Journal, 20(2), 195204. https://doi.org/10.1002/(SICI)1097-0266

ILO. (1999). Ratifications for Saudi Arabia. Geneva: International Labour Organization. Retrieved October 9, 2020, from https://www. ilo.org/dyn/normlex/en/f?p=NORMLEXPUB:11 200:0::NO::P11200_COUNTRY_ID:103208

ILO. (2012). Establishment of a Policy and Strategy Unit at the Ministry of Labour of the Kingdom of Saudi Arabia. Geneva: International Labour Organization. Retrieved October 9, 2020, from https://www.ilo.org/beirut/projects/ WCMS_229169/lang--en/index.htm

Järvis, M., \& Tint, P. (2009). The Formation of a Good Safety Culture at Enterprise. Journal of Business Economics and Management, 10(2), 169-180. https://doi.org/10.3846/16111699.2009.10.169-180

Kabacoff, R. (2017). R in Action. Greenwich, CT: Manning Publications Co.

Kahan, D. M., \& Slovic, P. (2006). Cultural Evaluations of Risk: 'Values' or 'Blunders'? (Working Paper No. 111). New Haven, CT: Yale Law School. https://doi.org/10.2139/ ssrn. 890800

Kaiser, H. F. (1974). An index of factorial simplicity. Psychometrika, 39(1), 31-36. https:// doi.org/10.1007/BF02291575

Kaufman, B. E. (1989). Labor's Inequality of Bargaining Power: Changes Over Time and Implications for Public Policy. Journal of Labor Research, 10(3), 285-297. https://doi. org/10.1007/BF02685272

Kaufman, B. E. (2004). The Global Evolution of Industrial Relations: Events, Ideas and the IIRA. Geneva: International Labor Organization.

Kaufman, B. E. (2008). Labor Law and Employment Regulation: Neoclassical and Institutional Perspectives (Working Paper No. 24). Atlanta, GA: Georgia State University.

Kaur, J., \& Sharma, S. K. (2015). Internal Marketing: Scale Development and Validation. Vision: The Journal of Business Perspective, 19(3), 236-247. https://doi. org/10.1177/0972262915597088

Kelloway, E. K. (1998). Using LISREL for Structural Equation Modeling: A Researcher's Guide. New York, NY: Sage Publications.

Kerlinger, F. N. (1986). Foundations of Behavioral Research (3rd ed.). New York, NY: Holt, Rinehart and Winston.

Kim, J., \& Mueller, C. W. (1978). Introduction to Factor Analysis: What is it and How to Do it. Beverly Hills, CA: Sage. 
Korobkin, R., \& Ulen, T. S. (2000). Law and Behavioral Science: Removing the Rationality Assumption from Law and Economics. California Law Review, 88(4), 1051. https://doi. org/10.2307/3481255

Kumar, K., \& Beyerlein, M. (1991). Construction and validation of an instrument for measuring ingratiatory behaviors in organizational settings. Journal of Applied Psychology, 76(5), 619-627. https://doi. org/10.1037/0021-9010.76.5.619

Lenth, R.V.(2001).SomePractical Guidelines for Effective Sample Size Determination. The American Statistician, 55(3), 187-193. https:// doi.org/10.1198/000313001317098149

Lissitz, R. W., \& Green, S. B. (1975). Effect of the number of scale points on reliability: A Monte Carlo approach. Journal of Applied Psychology, 60(1), 10-13. https://doi. org/10.1037/h0076268

Lopez-Fernandez, O., Honrubia-Serrano, M. L., FreixaBlanxart, M., \& Gibson, W. (2014). Prevalence of problematic mobile phone use in British adolescents. Cyber Psychology, Behavior, and Social Networking, 17(2), 91-98. https://doi.org/10.1089/cyber.2012.0260

Manning, A. (2003). Monopsony in Motion: Imperfect Competition in Labour Markets. Princeton, NJ: Princeton University Press.

Meager, N., Tyers, C., Perryman, S., Rick J., \& Willison, R. (2002). Awareness, Knowledge and Exercise of Individual Employment Rights (Employment Relations Research Paper No. 15). London: The Institute for Employment Studies.

Miceli, T. (2004). The Economic Approach to Law (2nd ed.). Stanford, CA: Stanford University Press.

Nunnally, J. C. (1978). Psychometric Theory (2nd ed.). New York, NY: McGraw-Hill Book Company.

Odeh, R. E., \& Fox, M. (1991). Sample Size Choice: Charts for Experiments with Linear Models (2nd ed.). New York, NY: Marcel Dekker.

Omar, Z., Chan, K. Y., \& Joned, R. (2009). Knowledge Concerning Employees' Legal Rights at Work among Banking Employees in Malaysia. Employee Response Rights Journal, 21(4), 343-362. https://doi.org/10.1007/ s10672-009-9123-5

Park, H. M. (2015). Univariate Analysis and Normality Test Using SAS, Stata, and SPSS. Bloomington, IN: Indiana University. Retrieved June 12, 2021, from https://scholarworks. iu.edu/dspace/handle/2022/19742
Pleasence, P., \& Balmer, N. J. (2012). Ignorance is Bliss: Modeling Knowledge of Rights in Marriage and Cohabitation. Law \& Society Review, 46(2), 297-333. https://doi. org/10.1111/j.1540-5893.2012.00490.x

Posner, R. (2007). Economic Analysis of Law (7th ed.). Austin, TX: Wolters Kluwer.

Raes, F., Hoes, D., Van Gucht, D., Kanter, J. W., \& Hermans, D. (2010). The Dutch version of the behavioral activation for depression scale (BADS): Psychometric properties and factor structure. Journal of Behavior Therapy and Experimental Psychiatry, 41(3), 246-250. https://doi.org/10.1016/j.jbtep.2010.02.001

Rees, C., Alfes, K., \& Gatenby, M. (2013). Employee voice and engagement: Connections and consequences. The International Journal of Human Resource Management, 24(14), 2780-2798. https://doi.org/10.1080/09585192. 2013.763843

Repa, B. K. (1994). Your Rights in the Workplace (2nd ed.). Berkley, CA: Nolo Press.

Rowell, A. (2019). Legal knowledge, belief, and aspiration. Arizona State Law Journal, 51, 225-291. https://doi.org/10.2139/ssrn.2903049

Rubin, P. (1983). Business Firms and the Common Law: The Evolution of Efficient Rules. New York, NY: Praeger.

Rummel, R. J. (1970). Applied Factor Analysis. Evanston, IL: Northwestern University Press.

Schmitt, N. W., \& Klimoski, R. J. (1991). Research Methods in Human Resources Management. Cincinnati, $\mathrm{OH}$ : South-Western.

Schoenbaum, N. (2011). It's Time that You Know: The Shortcomings of Ignorance as Fairness in Employment Law and the Need for an 'Information-Shifting' Model. Harvard Journal of Law \& Gender, 30, 99-150.

Schriesheim, C. A., \& Eisenbach, R. J. (1991). Item wording effects on exploratory factoranalytic results: An experimental investigation. In Proceedings of the 1990 Southern Management Association Annual Meetings (pp. 396-398).

Schwab, D. P. (1980). Construct validity in organization behavior. In B. M. Staw, \& L. L. Cummings (Eds.), Research in Organizational Behavior (Vol. 2, pp. 3-43). Greenwich, CT: JAI Press.

Simon, H. (1978). Rationality as process and as product of thought. American Economic Review, 68(2), 1-16.

Sotshononda, N. (2019). Perspectives on protective promotion as a remedy to unfair 


\section{Business Administration and Management}

labour practices. Acta Commercii, 19(1), 1-5. https://doi.org/10.4102/ac.v19i1.764

Steiger, J. H. (2007). Understanding the limitations of global fit assessment in structural equation modeling. Personality and Individual Differences, 42(5), 893-898. https://doi. org/10.1016/j.paid.2006.09.017

Stone, E. (1978). Research Methods in Organizational Behavior. Glenview, IL: Scott, Foresman.

Sulphey, M. M., \& Upadhyay, Y. K. (2019). Construction and Validation of Micromanagement Questionnaire. International Journal of Environment, Workplace and Employment, 5(3), 193-205. https://doi. org/10.1504/IJEWE.2019.103378

Sulphey, M. M. (2020). Construction and validation of Workplace Identity Scale (WIS). Economics and Sociology, 13(2), 53-69. https:// doi.org/10.14254/2071-789X.2020/13-2/4

Swalih, M. M., Mathew, P., \& Sulphey, M. M. (2019). Adaptation of Smart Phone Addiction Scale. St. Theresa Journal of Humanities and Social Sciences, 5(1), 22-41.

Tamanaha, B. (2018). Functions of the Rule of Law. In M. Loughlin, \& J. Meierhenrich (Eds.), The Cambridge Companion To The Rule Of Law. Cambridge: Cambridge University Press.

Tossell, C., Kortum, P. T., Shepard, C., Rahmati, A., \& Zhong, L. (2015). Exploring
Smartphone Addiction: Insights from Long-Term Telemetric Behavioral Measures. International Journal of Interactive Mobile Technologies, 9(2), 37-43. https://doi.org/10.3991/ijim.v9i2.4300

Viswanathan, M. (1993). Measurement of individual differences in preference for numerical information. Journal of Applied Psychology, 78(5), 741-752. https://doi. org/10.1037/0021-9010.78.5.741

Wachter, M. L. (2012). The Striking Success of the National Labor Relations Act. In C. Estlund, \& M. L. Wachter (Eds.), Research Handbook on the Economics of Labor and Employment Law (pp. 427-462). Cheltenham: Edward Elgar Publishing.

Williams, B., Onsman, A., \& Brown, T. (2010). Exploratory factor analysis: A fivestep guide for novices. Australasian Journal of Paramedicine, 8(3), 1-13. https://doi. org/10.33151/ajp.8.3.93

Wu, A. D. (2008). Pratt's importance measures in factor analysis: A new technique for interpreting oblique factor models (Doctoral dissertation). Vancouver: University of British Columbia.

Yean, T. F., \& Yusof, A. A. (2016). Organisational justice Justice: A Conceptual Discussion. Procedia - Social and Behavioral Science, 219, 798-803. https://doi. org/10.1016/j.sbspro.2016.05.082 